\title{
CRITICAL ANALYSIS OF THERAPEUTIC POTENTIAL OF DALHANOKTA ARTAVA KSHAYA CHIKITSA
}

\author{
Dr. Madhu M ${ }^{1}$ \\ ${ }^{1}$ Associate Professor in the Department of Prasuti Tantra \& Stree Roga, \\ S.D.M College of Ayurveda \& Hospital, Hassan
}

\author{
Dr. Prasanna $S^{2}$ \\ ${ }^{2}$ Associate Professor in the Department of Rachana Shareera, S.D.M College of Ayurveda \& \\ Hospital, Hassan
}

Article DOI: https://doi.org/10.36713/epra6694 \begin{abstract}
and wellbeing. Women's health is most neglected due to the busy schedule, shyness, negligence, etc which in turn cause many incurable medical complications. Menstrual health is one of the most neglected areas of female illhealth. It is mainly due to improper knowledge about menstrual illness. Acharyas have described separate chapters about these problems and their treatments. Artava kshaya is one among them. Many treatment modalities are explained by Acharya Sushruta but Dalhana comments on the main principles of treatment which has good results in treating Artava kshaya. This paper is to critically analyze Dalhanokta Artavakshya chikitsa.
\end{abstract}

\section{INTRODUCTION}

Nidana of Artavakshaya

No specific etiological factors responsible for artava kshaya were mentioned in Samhitas. Mithya ahara, viharas, Factors responsible for rasa-rakta dhatu kshaya, Causative factors for the vitiation of tridoshas can be mentioned as the nidanas of artavakshaya. Dalhana, the commentator of Sushruta has described the various etiological factors responsible for this condition, ${ }^{1}$ they are Atisamshodhana, Atisamshamana, Vega Dharana, Asatmaanna, Manastaapa, Vyayama, Anashana.

Samprapti: - The samprapti of artava kshaya involves two mechanisms.

\section{1) Dhatu kshaya janya}

2) Marga avarodha janya

In dhatu kshaya janya Artavakshaya, the vitiation of doshas occurs by their respective visiated ahara \& vihara. These vitiated doshas affect rasadhatu \& its dhatwagni. So there is rakta dhatu kshaya which is an anuloma kshaya.

In marga avarodha janya artava $\mathrm{kshaya}^{4}$, the involvement of doshas are Vata and Kapha. According to Charaka the vitiation of artava vaha srotas occurs through sanga. This avarodha (obstruction) is caused either by Kapha or Vata alone or Vata- kapha together.2,4 According to Sushruta, Vata - kapha are the factors causing avarana to artava vaha srotas. Pitta is not included because it causes artava vriddhi ${ }^{3,4}$. Sushruta has also explained that the trauma or injury to artava vaha srotas causes vandhyatwa (infertility), maithuna asahishnuta (dyspareunia) \& artava nasha.

The treatment aim here is to relieve the obstruction caused by kapha or/\& vata to the artava vaha srotas. After performing Snehana \& Swedana karmas, Vamana karma in case of kapha vitiation can be done. Niruha $\&$ anuvasana basti are indicated in vata 


\section{EPRA International Journal of Research and Development (IJRD)}

vitiation. Uttarabasti can be indicated in obstruction caused by kapha \& vata.

Rupa5: -

\section{"आर्तव क्षये यथोचित काल अदर्शनम् अल्पता वा}

योनिवेदना च ॥ (Su. Su. 15/12)

Means the artava does not appear at the appropriate time or if present, it would be alpa in pramana and associated with Yonivedana ${ }^{1,6,7}$.

Chikitsa (treatment): - 5,6

"तत्र संशोधन आग्नेतानाम्म च विधिवत्त उपयोग : ।I"

(Su. Su. 15/12)

Artavakshaya should be treated by use of purifying measures \& Agneya dravyas.

\section{DALHANOKTA CHIKITSA Material and methods}

Analysis of Dalhanokta artavakshaya chikitsa i.e Vamana karma is to be done not Virechana, followed by Agneya dravya Upayoga 5 .

Dalhana says that for purification, only Vamana karma should be used, no Virecana because Virechana eliminates pitta which in turn reduces Agneyatva in the body,. Vamana karma does Sowmya dhatu nirharana,consequently, artava also increases. Agneya substances i.e. tila, masha, wine \& sukta can be used.

\section{Poorvakarma}

1. Deepana Pachana - till nirama dosha lakshana[35days]

2. Snehana:

A) Abhyantara - Arohana krama, till samyak snigda lakshana appear $[</=7$ days $]$

B) Bahya sneha

3. Swedana- Bashpa sweda till samyak sweda lakshana[for 1day]

Pradhana karma:_Vamana karma with Madanaphala yoga

Paschat karma

1. Dhoomapana

2. Samsarjana karma-according to Shuddi

After Vamana karma, Agneya dravya is given to increase the Arthava.

\section{DISCUSSION}

Kaphaprakopaka ahara-vihar by kaphaprakruthi stree, there will be a visitation of Kapha dosha mainly, which causes meda vriddi. This causes visitiation of the menstrual cycle (Ritu chakra). It may cause Yathochita kala adarshana of arthva mentioned by Sushruthacharya. Also, vitiation of vata pradhana tridosha avarana to artavahastrotas. Thus it will lead to dushti of artavavaha strotas in terms of Artavakshaya along with this meda vriddhi.

\section{PROBABLE MODE OF ACTION OF VAMANA}

Vamanakarma : -

Vamana karma is a medicated emesis/vomiting therapy, which removes dushitha Kapha collected in the body. Vamana karma is done during Kapha prakopa condition. Vidhi poorvaka emesis therapy eliminates and expels vitiated kapha dosha through the upper GI tract. Thus by this treatment, the prakupita kapha is eliminated out through the mouth from the koshta.

The effect of vamanakarma on the entire body system can be explained by the concept of regulation of homeostasis by the nervous system\& endocrine system: A hypothetical approach. There is an imbalance of dosha in the diseased condition which means normal homeostasis is disturbed.

Deepana - pachana: Enzymatic system or metabolic activity of the body is activated at intracellular \& circulatory level, which are under the control of centers in the brain. Mild action on the local autocrine, paracrine gland may be noted. Thus the body is made to face further disturbances.

Snehapana: A closely monitored \& systematically controlled physiological, pathological changes are artificially made through the oral administration of sneahapana to disturb homeostasis for which the body responds positively or negatively through a feedback mechanism system. Thus systems are activated or suppressed, bringing changes at the molecular level, ionic level, cellular level, tissue level, etc. Anabolic, catabolic process (like breaking down, rearranging, remodeling, restructuring in chemical constituent, ionic bonds, etc) in the body is activated or suppressed through various physiochemical principles involved in the body.

Swedana: Adjustment to the changes caused by the external environment to that of the internal environment is the main concern of the homeostatic system. By subjecting the body in a programmed manner to abhyanga \& swedana further disturbance is made in homeostasis. Swedana increases microcirculation - again rearrangement of bodily chemicals----inducing stress ---- feedback mechanism activated -separation of toxin----movements of this from extracellular to intercellular space creating a lot of changes in biochemical constituents of the body.

Vishranti day: By following this, a time is given to the system to come back naturally in the process of conversion, separation, formation reunion etc of molecules.. It is for one day in Vamana may be only such physio chemical molecule can take part. Providing kaphakara aahara may be to increase such physio chemical activities.

Vamana karma: An intervention to make the body come back to the normal state of homeostasis which 


\section{EPRA International Journal of Research and Development (IJRD)

is strictly observed by maniki, lingiki, antiki lakshanas.

Samsarjana karma: - Body is made fit again or for faster systematic rejuvenation is achieved in a natural way allowing all the system to improve in its way.

\section{Mode of action of vamana Aushadhi: -}

The vamana aushada is comprised of qualities like Ushna, Tikshna, Sukskma, Vyavayi, Vikasi and formed with a predominance of agni and vayu mahaboota. But the main action is attained by the urdhvabhagahara prabhava possessed by these drugs. The drugs due to their virya will reach hridaya and dhamani thereby reaches Stula and anu srotas of body. The vyavayi Guna of the drug will help in the quick absorption and movement of the drug. Vikasi Guna will help in breaking the binding of dosha and dushya. Due to Ushna Guna drug will cause vishyandhana and due to Tikshana Guna causes Chedhana of Doshas. The Sukshma Guna helps to reach minutest channels Agni and Vayu mahabhutha because of its qualities like laghutva and tendency to move upwards will help in bringing Vamaka effects. More importantly, Prabhava of the drug is especially responsible for bringing about the Vamana action.

While describing the act of Vamana, Charaka has used the word, "Udana Pranunno" on which Chakrapani comments that Vamana drugs lead to upward direction due to Udanavayu \& has the prime role in conducting the whole Vamana process as it occurs in its site. Charaka narrates the sites of Udanavayu as Nabhi, Utah \& Kantha. Vagbhata also supports his view \& adds new site like 'Nasa'and plays a role in activating Dhi, Mana, continuous changes of Fight or Flight emotions, Thus, Udana Vayu helps the Vamana drugs to remove the extracted matter through an exhaustive process of Vamana which indicates an involvement of nervous system

Dhamani are the channels that carry some constituents with them. Definition "Dhmanat dhamanyah" means which pulsates. Thus, it is the structure resembling the artery. Chakrapani also comments that it provides nourishment to Paramanus. So, in the Vamana process, dhamani is the medium through which Vamana drugs reach the cellular level for their purpose. He remarks that vamaka drugs remain there themselves $\&$ pass the impulses towards several areas throughout the body through dhamani. This distinctly points to the conduction of impulses through the means of the nerves Thus the act of Vamana proceeds through both the systems i.e circulatory \& nervous systems.

Hrudaya: The drugs, due to their "Swavirya" reach Hrudaya from where they spread all over the body. To reach the micro-level through the body in a very short time, chief systems are circulatory \& nervous. As it is said that Vamana drugs move into dhamani after passing from Hrudaya, one can say that here the word "Hrudaya" may have both meanings, showing the involvement of both the vital \& chief organs i.e. Heart \& Brain.

Aakantapana of milk causes stretching of stomach, initiating stretch receptor to send the neurological signal through the vagus nerve to vomiting centers in the brain, after taking madanaphala yoga chemoreceptor to detect the change in ph of the stomach content \& send the signal to the brain, thus initiating the act of Vamana without absorption of the drug.

The process should be completed within $45 \mathrm{~min}$ because after $20-25 \mathrm{~min}$ a peristaltic movement starts at funds which may interfere in the antiperistaltic movement of

\section{Vamana}

The probable mode of action of vamana in Artava kshaya is mainly dosha pratyaneeka.

By deepana, pachana. Snehapana, swedana(poorvakrama) in a systematic way help in the separation, mobilization, and liqification of morbid Kapha ( ? altered biochemical constituents). (b)sex hormones namely estrogen. androgen is formed only by cholesterol hence intake of snehapana may help in their formation (c)snehapana will promote the selection of dominant follicle (e)Make Estrogen, FSH, etc receptor to activate. (f) Vamana karma \& samsarjana karma brings back doshic imbalances. Thus practiced line of treatment of modern medicine weight reduction, decreasing in insulin-like growth factor, harmonizing the hormone can be achieved by vamanakarma.

Ayurveda identifies the dominance of Kapha doshaSoumya dhatu as an important causative factor in artvakshaya.\& removal of this is achieved by vamanakarma to maintain agneya tatva in the normal condition a possible approach correcting at this level. Agneya dravyas:

Drug action depends upon the rasa, guna virya, vipaka, and prabhava of the drug.

The drugs are having agneya quality which is responsible for vata, shaman, and pitta vardhana. The pharmacological action of these drugs is responsible in two ways i.e., one is to improve the dhatus and the other is to stimulate menstruation.

\section{CONCLUSION}

Different modalities of treatment are explained for Artava kshaya. Among them, the samshodhana is an important one. Vamana and Virechana both are found to be helpful in clinical practice. The concept of Vamana karma explained by Dalhanacharya seems to be more beneficial in avarana janya Artava kshaya. It acts by eliminating 
the saumya dhatu in turn increasing the pitta which finally elevates the artava. Thus helping in treating Artavakshaya.

\section{REFERENCES}

1. Vaidya Acharya Jadavji Trikamji and Acharaya Kavya Tirtha Narayan Ram \& Prof. Sharma P.V. Sushruthasamhita of Sushruta with the Nibandha Sangraha Commentry of Shri. Dalahanacharya and the Nyayanchandrika Panika of Shri Gayadasacharya on Nidansthana, Varanasi, Chaukhamba Orientalia, 1997.

2. Agnivesha, Charaka Samhitha with Ayurveda Dipika commentary of Chakrapanidatta; Edited by Vaidya Jadavji Trikamji Acharya; Chaukambha Orientalia; Varanasi; Reprint 2009.

3. P.V. Tewari. Ayurvediya Prasutitantra evam Striroga. Part II, Striroga, II edition, Varanasi, Chaukhambha orientalia, 2000.

4. Madhu.M: Vamana Karma: A Successful Treatment of Artava Kshaya (Oligomenorrhoea)A Case Report. ayurpub 2017;II(1):322-325

5. Vaidya Acharya Jadavji Trikamji and Acharaya Kavya Tirtha Narayan Ram \& Prof. Sharma P.V. Sushruthasamhita of Sushruta with the Nibandha Sangraha Commentry of Shri. Dalahanacharya and the Nyayanchandrika Panika of Shri Gayadasacharya on Nidansthana, Varanasi, Chaukhamba Orientalia, 1997.

6. V.N .K Usha, Text book of Streeroga, Chaukhamba Sanskrit Pratishtana Delhi, 2013.

7. Madhu M: Non-Hormonal Treatment of Hyperprolactinemia - A Case Study, Int J Ayu Pharm Chem 2019, Greentree Group Publishers (C) IJAPC Vol. 10 Issue 3 